\title{
TRAMAS TRANSANDINAS \\ DINÁMICAS CULTURALES DEL TEXTIL ANDINO
}

\author{
POR \\ MeritXell Hernando Marsal \\ Universidade Federal de Santa Catarina
}

El textil ocupa un lugar central en la cultura andina, transmitiendo valores sociales, políticos, religiosos y estéticos. Su función en la configuración social de los Andes fue central para las distintas culturas de la región y pervive en la actualidad.

Más allá de la necesidad de cubrirse, el textil comporta, según Denise Arnold, "envolverse en una piel social de imágenes poderosas" (214), y deviene una forma de diálogo de la identidad y la diferencia en la producción de representaciones culturales propias. Su importancia está codificada en la mitología. Es el atavío lo que separa al ser humano frente a los animales, otorgándole rasgos civilizatorios (Rodríguez 236). Viracocha, dios multicultural, entreverado con el Tunupa aymara (Gisbert 8), en una de sus manifestaciones está relacionado con la ropa, que lo auxilia en el ordenamiento del mundo. Al crear la humanidad después del diluvio, hace que los hombres surjan en diversos lugares sagrados, las huacas, reveladas en sus vestiduras. De esta manera, las ropas manifiestan origen y linaje y distinguen a cada pueblo (Gisbert 8).

El arte textil deviene, por tanto, un fuerte lazo identitario, en un hacerse y transformarse continuo, en diálogo permanente con otros signos. Además, en él se expresa una interpretación del mundo andino, que las tejedoras pasan a las nuevas generaciones. Sophie Desrosiers, al investigar la pervivencia de las técnicas de tejido andinas, ha podido postular la existencia de "lógicas de pensamiento que imperan, tanto en la producción del mundo material como en la construcción del mundo conceptual" (340). En los tejidos (en sus elementos técnicos, en los espacios simbólicos que producen) se articularía el dualismo que asegura la complementariedad y reciprocidad de los opuestos (hanan/hurin, urcu/uma, vertical/horizontal, femenino/masculino) en los Andes. Por tanto, la organización social estaría inscrita en el textil, así como el propio entorno ecológico en el que se da la vida, pues cada tejido distingue lo árido de lo cultural, esto es la pampa (espacio no decorado) y el pallai (espacio con significado). Por ello, el tejido guarda la memoria social y deviene un arte de resistencia contra la presión colonial. Prueba de ello son las ordenanzas de Toledo, y después de Areche, vinculadas específicamente a las formas y contenidos del vestir. A pesar del propósito 
hispánico de fiscalizar el significado cultural de los textiles, prohibiendo ciertos dibujos y atuendos, Sophie Desrosiers asegura su papel determinante en la resistencia cultural, pues sus técnicas y convenciones continúan sosteniendo un fuerte sustrato simbólico (325). Como señala Teresa Gisbert, "la ropa se convertía en una especie de nexo entre la persona y el mundo exterior, físico y metafísico" (21).

Es necesario subrayar el protagonismo femenino; son las mujeres las que guardan el secreto de las tramas y las transmiten a sus hijas. De este lazo generacional se deriva la extraordinaria persistencia de formas y técnicas, a pesar del embate del mundo occidental desde la colonia. Se trata, sin duda, de un fenómeno de larga duración, que asegura profundos rasgos culturales.

En ese sentido, el textil andino puede ser comparado, como lo hace Gisbert, con manifestaciones de las artes occidentales, como la pintura. En este ensayo, voy a acercar al textil a otra tecnología con la que está íntimamente vinculado, a saber, la escritura. Etimológicamente, texto y tejido comparten la misma raíz latina, texere (Corominas 560), de manera que el pensamiento y la imaginación se enhebran con las palabras a la manera de los hilos en la trama. Y en cierto modo, de forma literal, no están tan alejados, pues los textiles también codifican un significado. Son formas de expresión visual y en cierta manera pueden ser considerados "verdaderos documentos"(Gisbert 23).

Pero para un enfoque transandino hay una dimensión del textil que importa ser destacada, y es su carácter relacional. El textil se configura como cuerpo de intercambio, vínculo dinámico entre diferentes comarcas (entre el altiplano, la costa que provee el algodón y la selva que aporta materiales como las plumas). Como señala Denise Arnold, el seguimiento de las rutas textiles impide ver las culturas andinas como paradigmas estáticos y fijos en el espacio y el tiempo (206), y permite señalar las interrelaciones históricas, políticas, religiosas, económicas y lingüísticas que se dan entre las diferentes comunidades. El arte textil se renueva constantemente en su vínculo con otras áreas, que aportan motivos, técnicas y diseños. Además deviene lazo de intercambio y comercio, tanto a nivel individual como comunitario, en las fiestas y ferias regionales.

Así propongo pensar el textil como un tema que nos permite observar la configuración regional de la cultura andina, superando la fragmentación política republicana, y percibir sus vínculos con otras áreas culturales. ${ }^{1}$ Para ello partiré de obras literarias donde lo textil se inscribe, temática o estructuralmente, asumiendo sus valores culturales y su movilidad: Nueva corónica y buen gobierno, de Felipe Guamán Poma de Ayala, El pez de oro, de Gamaliel Churata, y una obra contemporánea, Cuando Sara Chura despierte, de Juan Pablo Piñeiro. En ellas, el texto tejido hace las veces de paxp'aku, el personaje embaucador de la novela de este último:

Estas configuraciones también han sido leídas mediante la metáfora del archipiélago, ver las contribuciones de Ulises Juan Zevallos Aguilar y Marco Thomas Bosshard en este volúmen.

Revista Iberoamericana, Vol. LXXXI, Núm. 253, Octubre-Diciembre 2015, 1033-1050 
Al despertar supo que las monedas eran pieles, y que el albur de su vida debía ser la eterna mudanza. Así, habitando las distintas posibilidades de ser otro, olvidaría la pesada máscara que heredó del mundo. Él era el paxp'aku, el especialista en dar gato por liebre, marear la perdiz, dorar la píldora y contar el cuento del tío. Él era el ilusionista, el que con palabras podía crear una piel para después vestirla. (14)

\section{Los telares de Guamán Poma}

Guamán Poma es la principal fuente de documentación gráfica sobre arte textil prehispánico de la zona andina (Solanilla 89). En su Nueva corónica y buen gobierno ofrece gran cantidad de información sobre el valor central del textil en la sociedad incaica, su producción y sus usos sociales, económicos y religiosos. Las imágenes, además, nos proveen de registros muy valiosos de las formas y diseños de las ropas en tiempos de los incas.

Para abordarlo, quisiera seguir el proceder de la "sociología de la imagen" de Silvia Rivera Cusicanqui, que destaca el registro visual como forma de contra-narrativa, "que a la vez revela y reactualiza muchos aspectos no conscientes del mundo social" (Ch'ixinakax 19), frente a la función encubridora de la palabra, privilegiada en el contexto colonial como el vehículo sancionado. Uno de los referentes destacados por esta investigación imagética de Rivera Cusicanqui es la obra de Guamán Poma, que según la autora desarrolla "una teoría visual del sistema colonial" (Ch'ixinakax 14).

Como señala Antonio Cornejo Polar, si Guamán Poma adhiere al género de la crónica hispánica, en la forma de una larga carta al rey Felipe III, lo desarticula e interfiere al incluir el quechua como lengua vehicular y la imagen como suplemento de la letra:

De hecho, los dibujos de Guamán Poma dicen mucho más sobre el mundo andino que el español rudimentario con que está escrita la Nueva Crónica [...] y su sola presencia indica la acción de una dinámica inversa: si en otros casos el proceso productivo sofocaba el referente, en éste, al contrario, el referente puede imponer ciertas condiciones y generar una modificación en la estructura formal de las crónicas. (77)

Las imágenes exceden lo dicho, denunciando, de forma acuciante, como señala Rivera, la inversión del mundo:

Más que en el texto, es en los dibujos donde el cronista despliega ideas propias sobre la sociedad indígena prehispánica, sobre sus valores y conceptos del tiempo-espacio, y sobre los significados de esa hecatombe que fue la colonización y subordinación masiva de la población y el territorio de los Andes a la corona española. (Ch'ixinakax 22)

Guamán Poma en su capítulo sobre el censo nos muestra cómo el arte textil era el principio ordenador de la vida y convivencia de las mujeres en la sociedad incaica,

Revista Iberoamericana, Vol. LXXXI, Núm. 253, Octubre-Diciembre 2015, 1033-1050 
otorgándoles su lugar en el mundo. Así, Guamán las dispone local y cronológicamente en diez calles según sus edades y habilidades en el telar, estableciendo una jerarquía femenina fundada en el servicio a la comunidad. Lejos de una valoración objetual, la mujer alcanza su dignidad por sus habilidades y experiencia, vinculada al textil. Guamán construye un orden "urbano", que implica toda una jerarquía social. Este orden de calles constituye a su vez un orden ideológico que construye, en oposición al presente colonial, una imagen ennoblecida del pasado incaico y sus estructuras sociales, que destacarían por su justicia y equidad.

La primera calle (160) la ocupa la mujer de treinta y tres años, que alcanzó el dominio de las técnicas textiles.

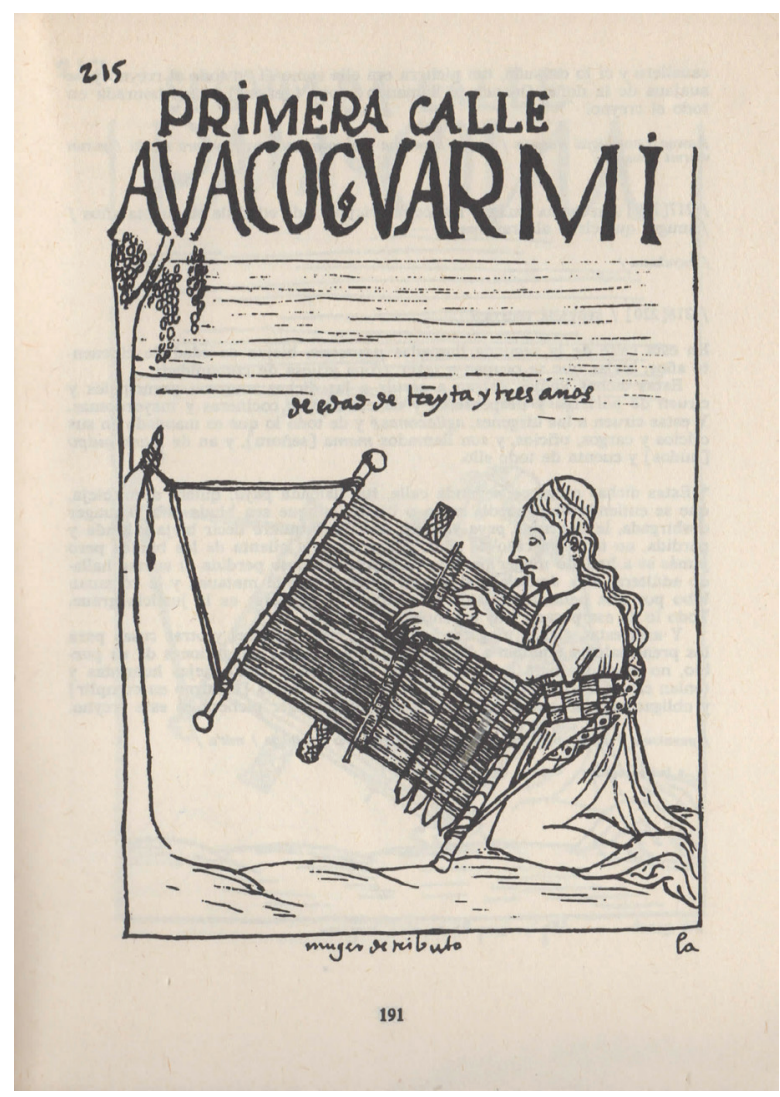

En la imagen se la ve concentrada en un telar de cintura, en que se distingue claramente la urdimbre de la trama. Primera entre todas, porque ella es la mujer de

Revista Iberoamericana, Vol. LXXXI, Núm. 253, Octubre-Diciembre 2015, 1033-1050 
tributo, lo cual alude a la organización económica del estado incaico, que implicaba dos obligaciones principales para el conjunto de la población: el trabajo de la tierra y la elaboración de tejidos. Material precioso, estos se convertían en cuerpo itinerante, dirigidos al culto o almacenados en depósitos del Estado.

La segunda calle, la de la mujer de cincuenta años (161), también está ocupada por un telar de cintura: es la mujer que entró en la vejez, pero sigue tejiendo ropa gruesa y sirve a una señora principal. Ya la tercera y cuarta (163-164) están destinadas a las ancianas y tullidas, que contribuyen en sus posibilidades, y no tienen necesidad de limosna. La calle central, la quinta (166), corresponde a las mujeres solteras de hasta treinta y tres años.

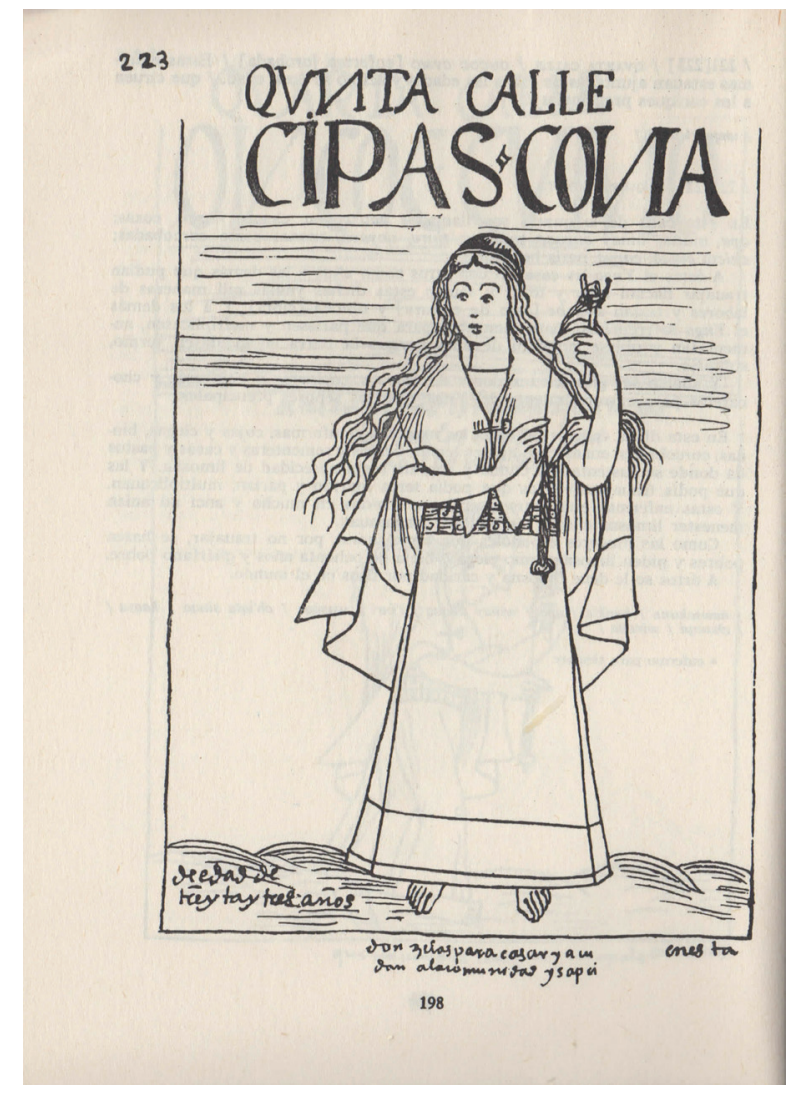

Es notable la belleza de esta figura, que ocupa el centro del espacio, vestida con el acsu y la lliclla, los pies descalzos y el pelo suelto. En las manos tiene un huso que

Revista Iberoamericana, Vol. LXXXI, Núm. 253, Octubre-Diciembre 2015, 1033-1050 
alude a sus habilidades. Virgen, está dispuesta para casarse o para servir a los dioses y al Inka, como aclla. Esto nos remite a la imagen del "convento" (223), el Acllahuasi, donde Guamán representa a todas las "monjas" con un huso en la mano, pues su principal labor era el tejido de ropas finas para ritos religiosos y para el Inka.

Finalmente, de la sexta a la décima calle (167-173), las mujeres se disponen en orden decreciente de edad, aludiendo a su aprendizaje progresivo en las artes del tejido, de doce a dieciocho años, a la recolección de plantas para el tinte a los nueve, a la iniciación en el hilar a los cinco, y al cuidado con que son guardadas en sus primeros años: "Desde que salió de la vientre de su madre fue repartida tierras y sementeras, y le beneficiaban su parcialidad todo, sus compadres y comadres" (174).

Este orden vital, en el que la mujer accede a bienes y a responsabilidad social, y que pretende representar una armonía entre trabajo y mujer, será trastocado con la conquista. Es significativo como Guamán Poma regresa a la imagen del telar, descomponiendo la serenidad de las figuras, para introducir el dolor y el sinsentido. Como señala Mercedes López Baralt, en la obra de Guamán Poma se establecen vínculos entre dibujos distantes, discursivamente desconectados, "vinculados por una simetría más cercana al pensamiento mítico que al histórico" (200). Este es el caso de la referencia a la mujer y el tejido. Son las imágenes las que comunican la profunda ruptura de un orden de vida.

El capítulo dedicado a los padres de doctrina (450) se inicia casi con la imagen de la primera calle, pero en la que incide un nuevo personaje: un religioso amenaza con un palo a la mujer que teje, que parece la misma. Ella no está concentrada en el trabajo y en una actitud dolida se seca las lágrimas. La imagen trasparece impotencia e injusticia. Se trata de una de esas escenas en las que Mercedes López-Baralt podría identificar una "retórica del grito", una indignada "vociferación visual": "parecen gritar tantas de las imágenes de Guamán Poma, por el horror de su contenido. Chillan particularmente aquellas que presentan la conjunción de sexo y violencia, y que confieren un carácter estridente al texto visual de la Nueva Coronica" (191).

Tal como ha estudiado Rolena Adorno la posición de los personajes en el espacio del dibujo comunica más allá de lo representado. Esta imagen despliega una disposición horizontal en que el orden andino se ha trastocado: si el espacio hanan, a la derecha del dibujo (a la izquierda del espectador), debiera pertenecer a lo masculino, y el espacio hurin, a la izquierda, a lo femenino, nos encontramos con una posición invertida, de manera que el principio masculino occidental amenaza literalmente al femenino, deshaciendo la noción de complementariedad sexual andina. Aquí, como en otras escenas de abusos, "the violation of the pictorial spatial code denies again and again the notion that justice and order could reign under the Spanish colonial regime. The symbolic placement of images on the horizontal axis reiterates the story of the destruction of Andean society" (Adorno 111). En esta escena queda claro cómo la imposición del régimen colonial va aunada a la imposición de lo patriarcal, que

Revista Iberoamericana, Vol. LXXXI, Núm. 253, Octubre-Diciembre 2015, 1033-1050 


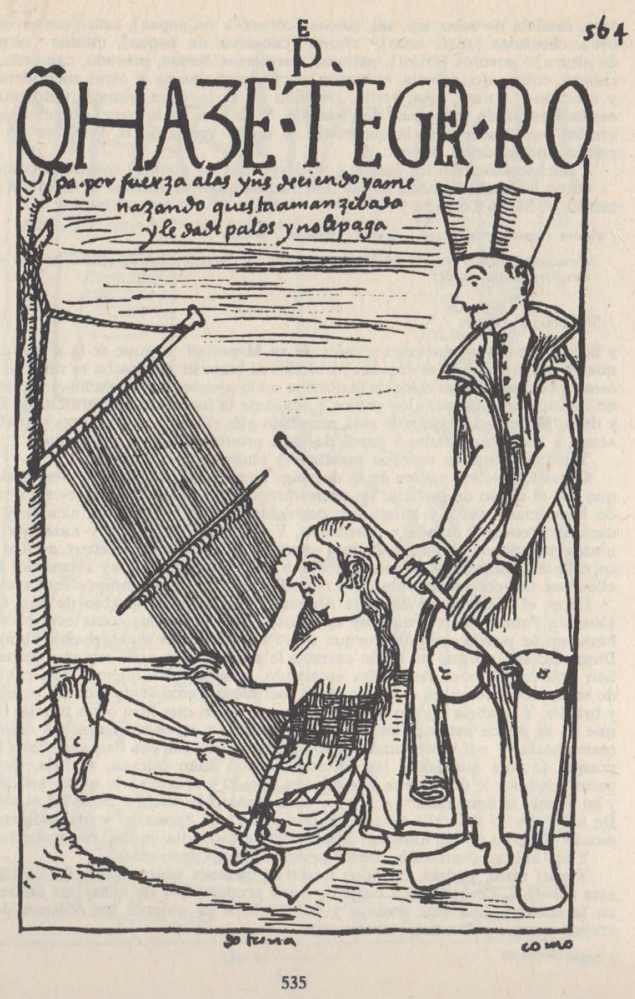

subyuga doblemente a las mujeres en el espacio colonial (Rivera, Violencias 205). De disponer de una posición complementaria (no igualitaria) a lo masculino en el sistema de filiación y parentesco bilateral andino, tanto en relación a bienes y derechos como a protagonismo social, las mujeres serán despojadas por la lógica occidental de su preeminencia social y relegadas al ámbito de lo doméstico.

Ahora bien, según Mercedez López-Baralt, en la disposición estructural de los personajes de Guamán también puede leerse la esperanza: “Al situar a la mujer andina en el lugar privilegiado de hanan, Guamán Poma la rescata para siempre de la victimización, devolviéndola a la dignidad de su humanidad lastimada" (181).

Esas mujeres abocadas a "parir mesticillos", el peor de los lastres coloniales según Guamán, pues desagrega totalmente la sociedad nativa, darán lugar a una sociedad inédita. Serán las mujeres y sus habilidades con el telar (además de la elaboración de la chica o el pastoreo) las que pondrán en funcionamiento una "apuesta femenina"

Revista Iberoamericana, Vol. LXXXI, Núm. 253, Octubre-Diciembre 2015, $1033-1050$ 
(Rivera, Violencias 193) por las ciudades, como mecanismo de supervivencia para superar la afrenta colonial y construir una sociedad propia:

Las nuevas realidades mercantiles y urbanas se formaron con su contribución activa, pero ellas y su prole tuvieron que pagar un precio muy alto, viviendo un nivel de conflicto que las obligó a aceptar un papel subordinado (como sirvientas, concubinas o segundas mujeres de un amo o amante español), en la esperanza de liberar a sus hijos/as de un destino como el suyo, proporcionándoles un espacio fronterizo en los intersticios de la sociedad colonial. (Rivera, Violencias 193)

El sometimiento al que la imagen de la tejedora alude no sólo hace referencia al orden social, sino también al sexual y al económico. En la comparación de estas escenas, vemos cómo la producción textil es disociada de sus funciones sociales e integrada en la razón capitalista por los españoles. Otra lógica se instala en las imágenes, desde la propia disparidad de los personajes, que como en el código andino son distinguidos por las ropas que visten. En la avidez por el tejido, semejante a la del oro, trasparece el imperativo del lucro y la sumisión del trabajador, que no es retribuido por su trabajo. El tejido en estos casos deja de estar integrado a la vida social, con sus mecanismos de reciprocidad, y esclaviza a su hacedor, al someterlo a una producción abstracta y sin finalidad comunitaria. De esta manera, los tejidos van a entrar de lleno en el trajín colonial, en sus redes de intercambio, como producto precioso a costos reducidos. Esta intervención del cura en el telar coloca el tejido en un circuito de intercambio global, pero vaciándolo de significado.

Silvia Rivera destaca "el nexo entre explotación laboral y desorden moral" que elaboran las imágenes. Más allá de la ambición de los religiosos, la crítica de Guamán denuncia la desarticulación de un orden, totalmente desquiciado por la situación colonial: “estamos ante una crítica mucho más severa y profunda a la explotación laboral, que se definiría ya no como extracción de plus trabajo sino como afrenta moral y un atentado contra la dignidad humana" (Ch'ixinakax 26).

Las imágenes de Guamán nos remiten como un flash back, en la terminología cinematográfica de Rivera Cusicanqui, a la actualidad transandina de los trabajadores textiles en São Paulo o Buenos Aires. El tejido representa una actividad económica muy lucrativa que responde a movimientos migratorios a gran escala, en que las formas del capitalismo global (grandes marcas como Adidas o Tucci) se aúnan con la informalidad, para dar lugar a apropiaciones subalternas de los procesos productivos (los dueños bolivianos de los talleres emplean a paisanos, que reclutan en sus provincias) pero también a nuevas formas de explotación.

Los talleres textiles son los responsables de la presencia innegable de lo andino en las metrópolis de Sudamérica, que se deja ver en las calles, las ferias, las fiestas y el tejido urbano. En São Paulo se inscribe en el propio espacio al apropiarse de la

Revista Iberoamericana, Vol. LXXXI, Núm. 253, Octubre-Diciembre 2015, 1033-1050 
Praça Kantuta, denominación híbrida, portugués/quechua, que ubica la feria donde cada domingo se reúnen los migrantes bolivianos y peruanos. Como la novela Bolivia Construcciones de Sergio di Nucci parece enunciar literalmente, signos y prácticas identitarias se reinventan y funcionan en estos nuevos contextos.

Pero si Bolivia Construcciones nos plantea la inserción exitosa de lo boliviano en las metrópolis sudamericanas, en un lenguaje humorístico y auto-irónico, a dos pasos de la feria está la contracara de esa experiencia ${ }^{2}$. Me interesa un fragmento de periódico, inserto como al acaso en la novela, que actualiza las imágenes dolorosas de Guamán Poma en forma de pesadilla contemporánea: “Jeannette Ruizpor vino hace 7 años a este país en busca de un futuro mejor, pero para sobrevivir a la villa 1-11-14 del Bajo Flores, junto a sus dos hijas, trabajó durante años, 14 horas diarias, en un taller de coreanos" (Morales 68).

Para obtener sus prendas a precios ínfimos, las grandes marcas acuden a estos talleres, muchos de ellos regentados por bolivianos o coreanos. Se come y se duerme en el taller, con jornadas extenuantes de más de diez horas. En este contexto, las prácticas sociales andinas basadas en el parentesco y la reciprocidad son aprovechadas para la explotación en fenómenos de "colonialismo interno" que establece "cadenas de relaciones de dominación colonial” (Rivera, Violencias 77), complejizando la dicotomía de opresión de lo andino por lo occidental, en "una amplia gradación de posiciones relativas y situacionales" (Rivera, Violencias 147).

En este contexto, el cuestionamiento y continua reconfiguración de la identidad cobra importancia en iniciativas civiles como las de los colectivos "Simbiosis y Situaciones", ambos ubicados en Buenos Aires, que se proponen contar y discutir lo sufrido para "cuestionar el sistema de producción de jerarquías en el mundo del trabajo y la migración" (Colectivo 7). De esta forma, la experiencia migrante y transnacional huye de la tipificación y el exotismo, que en cierta manera roza el texto de Sergio di Nucci, y explora reflexivamente los modos "en que la vida común se resiste a ser restringida y gobernada por medio de mecanismos como el racismo y el uso fijo y reaccionario de las fronteras y las identidades culturales" (Colectivo 7).

\section{LA TRAMA DE EL PEZ DE ORO}

Como es sabido, Gamaliel Churata toma directamente el relevo de Guamán Poma. Tanto lingüística como conceptualmente, su proyecto reclama tempranamente esta filiación, pues el manuscrito de Guamán fue editado en La Paz en 1944:

2 Este silenciamiento de los desgarradores aspectos sociales de la inmigración boliviana a la Argentina en las novelas de Bruno Morales (Sergio di Nucci) lo acusa también Dieter Ingenschay en su contribución a este volúmen.

Revista Iberoamericana, Vol. LXXXI, Núm. 253, Octubre-Diciembre 2015, 1033-1050 
De lo anterior no se saque que en EL PEZ DE ORO se pretenda ofrecer el paradigma de ese nuevo idioma indo-hispano, y menos de uno medularmente americano; si como fruto modesto y honesto de una actitud que tiene la insignificancia y edad de su autor, apenas luce-menos por decisión literaria que hábito-incrustaciones indias más pintoresquistas que sustantivas, intentos débiles por arrancar del cordaje hispano la melodía sanguínea. Pero que de intentos de esta índole surja al fin un idioma americano, a seguirse el buen camino de Huamán, si entiendo bien, será fruto de los escritores que lo intenten con genio y con amor de plebe. (17)

En varios textos he intentado pensar este proyecto lingüístico en el que se sustenta la obra. El lenguaje, en su tensión entre el castellano, el quechua y el aymara, da fundamento a un horizonte cultural andino que reclama los límites míticos del lago Titikaka. Con este entramado lingüístico, Churata supera los lindes coloniales y republicanos que partieron en dos el lago sagrado y propone un hibridismo en la lengua y la cultura que convoca un marco panandino y quizás también transandino. Lo cual conlleva, y en ello discurre la densidad de esta obra, relaciones conflictivas, flujos e intercambios notables (aparecen en ella personajes míticos como el puma de oro y la sirena del Titikaka, escritores como Cervantes o Santa Teresa, conquistadores y ancestros, prácticas chamánicas junto con sesiones psicoanalíticas). Pero la tensión es tanta, que muchas veces me he preguntado sobre la convicción de ese hibridismo. Ahora, me gustaría pensarlo bajo las formas de un tejido.

El pez de oro se estructura en 10 secciones que siguiendo el subtítulo de la obra pueden ser comprendidas como las diversas escenas de un retablo mestizo. Como señaló José María Arguedas en su ensayo "Notas elementales sobre el arte popular religioso y la cultura mestiza de Huamanga", el retablo es una forma de arte popular en que lo andino y lo cristiano se imbrican con un fuerte contenido mágico y religioso, algo que también está presente en el intento de Churata. Esta estructura tiene como núcleo central "Mama kuka", que en su condición de planta sagrada alimenta toda la obra. Esta sección podría ser entendida también como el centro o taypi que organiza la materia narrada, produciendo una simetría en espejo, como en un tejido. En efecto, a ambos lados de "Mama kuka", el libro empieza y termina con una sección llamada "El pez de oro". En el capítulo central se desarrolla un ritual chamánico que sostiene la voz narrativa sobre la vida y la muerte gracias a la invocación de la coca. ${ }^{3}$ Como veremos, el vínculo entre vida y muerte es central en el textil, tanto como lo es para Churata.

Pero el taypi también es el lago. Teresa Gisbert reseña los estudios de Thèrése Bouysse-Cassagne sobre el concepto espacial aymara, en que "el eje acuático es el taypi o centro":

Sobre la dimensión chamánica transandina en El pez de oro, marcada por la centralidad de "Mama kuka", ver la contribución de Helena Usandizaga en este volumen.

Revista Iberoamericana, Vol. LXXXI, Núm. 253, Octubre-Diciembre 2015, 1033-1050 
A ambos lados, el territorio se divide en urco, que representa la montaña y lo masculino, al oeste, y uma, que representa lo húmedo y lo femenino, al este. Ambos sectores están en tierra de altura y a cada sector corresponde un yunga o tierra baja: alaa-yunga, que corresponde a la costa, al oeste; y manca-yunga, que corresponde a la selva, al este. (17)

Churata recupera esta concepción espacial y sitúa en el lago el origen de su proyecto literario, postulando, como señala Elizabeth Monasterios, una "vanguardia del Titikaka", bárbara, alternativa a los ismos europeos ("Uncertain" 557 y "La vanguardia plebeya..”). ${ }^{4}$ En el lago se inscribe la genealogía del Pez, y en él encontrará el reconocimiento de su pueblo. Pero el lago es también el lugar de la batalla donde hallará la muerte y, paradójicamente, el lugar de la masacre de donde surge la obra:

Y en la orilla del Titikaka, amontonaron mujeres preñadas, niños de pecho, ancianos anatómicos, phasñas y waynitus kheswas en la flor de la edad y con la edad de la flor mustia en los labios.

Sobre el montón de carne martirizada, un niño miraba al cielo con los ojos opacos. - ¡Kaka!... Criiii...

Allí naciste, trino; de este montón putrefacto, naciste, trino mío, Inka. (78)

Un canto de muerte, que parece salido de una de las pavorosas imágenes de Guamán, es el origen de todo el libro. En Churata, nacimiento y muerte violenta, fin y resurrección, se alimentan el uno al otro. Incomprensible para la melancolía occidental, la memoria de la destrucción, memoria, en fin, de la conquista, trae consigo su representación, la muerte una y otra vez ritualizada, y la regeneración efectiva.

Para comprender mejor este proceso es necesario volver al arte textil. Tanto Sophie Desrosiers como Denise Arnold han destacado que para las tejedoras la tela es una especie de ser viviente en elaboración (Arnold 213-14; Desrosiers 332). El textil está conectado a los muertos y a los vivos, a los ancestros y a las generaciones futuras. Según Arnold, los orígenes del textil andino aparecen relacionados con costumbres bélicas, en que los guerreros traerían al grupo las cabezas trofeo de los enemigos, que serían hiladas y tejidas por las mujeres. En el proceso el muerto se regeneraría, transformado en pariente:

De esta manera, las prácticas textiles que se elaboran en torno a los muertos foráneos, ahora convertidos en parientes, se vuelven el modelo organizador para una serie de procesos regenerativos, en el hogar, en el ayllu y más allá, en manos de las mujeres y materializado en el tejido y los intercambios en torno a ello. (215)

4 Sobre esta vanguardia bárbara como una contramarcha vanguardista a las ideologías nacionales, ver la colaboración de Elizabeth Monasterios en este volúmen.

Revista Iberoamericana, Vol. LXXXI, Núm. 253, Octubre-Diciembre 2015, 1033-1050 
Silvia Rivera ha señalado este proceso en relación a la ambigüedad del término aymara lari, que significa a la vez tío (por parte de madre) y extraño. La especialización femenina en las artes textiles y rituales les otorgaba a las mujeres la facultad de asegurar los rasgos culturales de la comunidad y de incorporar al extranjero al grupo: "la otredad no significaba la ausencia de la condición humana. Todo ajeno o extraño podía integrarse, a diversos niveles, a la cultura del grupo más fuerte, al pasar de la condición de extraño a la de pariente [...] Sin embargo, esto sólo era posible a través de las mujeres" (Violencias 185).

El proceso parece cercano a la "afinidad relacional", referida por el antropólogo Eduardo Viveiros de Castro, en relación con la antropofagia Tupi (también para los Tupi, enemigo y cuñado se designaba con la misma palabra, tovajar). En la antropofagia ritual, o en el sistema textil aludido por Arnold, no se trata de someter o asimilar al otro (esto es, volverlo un igual), sino de ser el otro en su diferencia:

Os Tupi desejaram os europeus em sua alteridade plena, que lhes apareceu como transfiguração [...] não se tratava de impor maniacamente sua identidade sobre o outro, ou recusá-lo em nome da própria excelência étnica; mas sim de, atualizando uma relação com ele (relação sempre existente, sob o modo virtual), transformar a própria identidade. A inconstância da alma selvagem, em seu momento de abertura, é a expressão de um modo de ser onde "é a troca, não a identidade, o valor fundamental a ser afirmado", para lembrarmos a profunda reflexão de Clifford. (206)

De esta manera, mediante la devoración o el matrimonio, aquel que era enemigo se convierte en algo proprio en su alteridad y se establecen relaciones de reciprocidad y obligación, en un mismo cuerpo social en continua transformación.

En cierta manera, lingüísticamente, Churata intenta este proceso. El quechua y el aymara son la urdimbre que pervive entreverada con la trama castellana, regenerando a los muertos y componiendo un único tejido social.

Las hebras hispanas se mezclan con las andinas y forman un tejido mixto, pero contrastado, aludido por la palabra allka, esto es, el blanco y negro mezclados y en contraste, a la que Verónica Cereceda vinculó con la relación de oposición y complementariedad andina awqa ("Aproximaciones" 196). En la misma línea, Silvia Rivera Cusicanqui privilegia la palabra aymara $c h$ 'ixi, que al aludir a la mezcla no sintética, apuntaría a la sociedad andina actual:

La noción ch'ixi, como muchas otras (allka, ayni) obedece a la idea aymara de algo que es y no es a la vez, es decir, a la lógica del tercero incluido. Un color gris ch'ixi es blanco y no es blanco a la vez, es blanco y también es negro, su contrario [...] La noción de "hibridez" propuesta por García Canclini es una metáfora genética, que connota esterilidad. La mula es una especie híbrida y no puede reproducirse. La

Revista Iberoamericana, Vol. LXXXI, Núm. 253, Octubre-Diciembre 2015, 1033-1050 
hibridez asume la posibilidad que de la mezcla de dos diferentes, pueda salir un tercero completamente nuevo, una tercera raza o grupo social capaz de fusionar los rasgos de sus ancestros en una mezcla armónica y ante todo inédita. La noción de ch'ixi, por el contrario, equivale a la de "sociedad abigarrada" de Zavaleta, y plantea la coexistencia en paralelo de múltiples diferencias culturales que no se funden, sino que antagonizan o se complementan. Cada una se reproduce a sí misma desde la profundidad del pasado y se relaciona con las otras de forma contenciosa. (Ch'ixinakax 70)

La relación entre las lenguas en El pez de oro obedece, según esta lógica, no al hibridismo, sino a una síntesis disyuntiva de elementos heterogéneos, que postulando relaciones, intercambios y contrastes, mantiene la diferencia. Se trata, como señaló Elizabeth Monasterios, de un principio difícil de asimilar para el pensamiento occidental que privilegia modelos dialécticos: "Los contrarios, en esta perspectiva, no buscan la armonía de un equilibro sino el contacto peligroso de sus diferencias" ("awqa" 758). Monasterios, siguiendo a Cereceda, vincula este principio con la dimensión estética del pensamiento andino, que posibilita la experiencia radical de la alteridad, y el contacto con lo desconocido y sobrenatural: "Queda implícito que en casos de extrema belleza los contrarios más radicales (lo alto y lo bajo, la vida y la muerte, los vivos y los muertos) se tocan, y que lo importante no es destacar el lado conocido del mundo sino la experiencia de sus rostros ocultos, la indagación de su otro lado" "“awqa"758).

De esta manera, la relación entre las lenguas en El pez de oro estaría vinculada a este principio estético donde el canto roza la muerte y la vida. Como Sophie Desrosiers descubría en la secuencia de los hilos andinos la permanencia de una lógica cultural, podemos postular que la trama lingüística que Churata compone, el tejido idiomático de su obra, procede del pensamiento andino. Ello deviene un desafío a las formas literarias vigentes donde lo indio constituía meramente el tema, el objeto del discurso. En Churata, lo andino es la estética.

Volviendo a la estructura de la obra, la imagino como un tejido $k^{\prime} i s a$ : desde el taypi central se organizan listas-capítulos a ambos lados, formando una composición matizada. Esta disposición fue estudiada por Verónica Cereceda en Chile, pero parece que tuvo su origen hacia los años 40 en el lago Titikaka, quizá basada en el efecto de la luz en la ondulación de las aguas del lago (Arnold 229). La $k$ 'isa tendría precisamente la función de mediación y fecundidad (Cereceda, "Semiología" 194). Según Denise Arnold, la expansión de este estilo expresa la movilidad e innovación propias de las culturas andinas, al ser asumido como expresión identitaria aymara en diversos lugares, desde el altiplano andino, al norte de Chile y Argentina. Fue desde la ciudad de la Paz, que acogió migrantes aymara procedentes del Titikaka, y su construcción reivindicativa de la identidad andina, a partir de fiestas como el Gran Poder, que la $k$ 'isa se transformó "en una paleta pan-altiplánica donde los hablantes de aymara en las periferias buscan enfatizar sus lazos con La Paz como el centro cultural principal de identidad aymara.

Revista Iberoamericana, Vol. LXXXI, Núm. 253, Octubre-Diciembre 2015, 1033-1050 ISSN 0034-9631 (Impreso) 
Aquí la $k$ 'isa parece ser el elemento clave para mediar conflicto, al unir una base de poder mucho mayor en torno a una estética en común" (Arnold 236).

El pez de oro como k'isa o como tejido importa para ver cómo la trama de relaciones que se establecen en la obra, entre opuestos irreconciliables, entre vida y muerte, entre castellano e idiomas andinos, da lugar a un objeto concebido como multiplicidad dinámica, relación en la diferencia, que al ser leído se regenera y transforma en un ser vivo, enigmáticamente persistente.

\section{RUTAS TEXTILES CONTEMPORÁNEAS}

Lafiesta paceña del Señor del Gran Poder es el tema de Cuando Sara Chura despierte, de Juan Pablo Piñeiro. Esta obra sorprendente es, literalmente, intencionalmente, un tejido andino. Su centro, el capítulo "El bolero triunfal de Sara", es el núcleo irradiador de la obra, construido como un canto o letanía, en función ritual, en torno a la posibilidad que da nombre a la novela. De manera que el texto se estructura a partir de ese centro o taypi en dos mitades complementarias: de un lado los personajes vivos, César Amato y don Falsoafán; de otro, los personajes muertos, Juan Chusa Pankataya y el cadáver que respira.

Pero el personaje central es femenino, Sara Chura, una chola caracterizada por su poder mítico, su tamaño y por sus impresionantes polleras. Pacha mama hiperbólica, ella es la fuerza antigua que sustenta la fiesta del Gran Poder, en una ostentación irrestricta de telas y adornos superpuestos, el baile arrollador, el despilfarro de energía y dinero. Sophie Desrosiers ha señalado el vínculo de los diseños andinos y los movimientos de la danza, explícitos aquí. La fiesta se convierte en una apoteosis de baile y color, en el que el textil adquiere el protagonismo:

Miles de bailarines ultimaban los detalles de su vestimenta junto a los bordadores que habían trabajado sin parar desde el mes de mayo. Morenos, diablos, llameros, tinkus y sicuris estaban listos para calzar sus disfraces y bailar en la entrada folklórica. Bailar para los devotos, era adorar al señor del Gran Poder; para los impíos, era ejercer una profunda libertad que brotaba de la misma fiesta. (15)

De esta manera, por medio de la danza y el derroche, se reafirma la identidad indígena y mestiza de La Paz. La novela, que traza innumerables recorridos urbanos, expresa la experiencia andina urbana contemporánea, alejando la comprensión de la identidad indígena del esencialismo que la identifica con lo tradicional o lo campesino. En la novela, la vivencia contradictoria y cambiante de la ciudad, no puede ajustarse a lo "originario".

Esta configuración urbandina (la palabra es de William Camacho en Principio Potosí reverso) reclama la contemporaneidad para formas de vida que se resisten al

Revista Iberoamericana, Vol. LXXXI, Núm. 253, Octubre-Diciembre 2015, 1033-1050 
estereotipo. Como señala Denise Arnold, la insistencia en lo andino corre el riesgo de convertirse en una definición previa, al modo del "orientalismo" referido por Edward Said (209). Frente a nociones esencialistas y estáticas que encierran la identidad en un ámbito rural y remoto, a modo de "adorno multicultural del neoliberalismo" (Rivera, Ch'ixinakax 59), en la novela de Piñeiro, sin embargo, la experiencia de la ciudad, a las órdenes de la fuerza mítica de Sara Chura, se encarna en el pajpacu, un personaje constituido en el cambio y el movimiento: "Miraba a las personas y se sentía un camaleón. Imaginaba los infinitos caminos que se cruzaban en ellas y trazaba líneas invisibles que los unían. La calle era un escenario, siempre distinta en el que César imaginaba ser todos los personajes a la vez" (17).

Rosario Rodríguez señala la pluralidad encarnada en las pieles que visten los personajes de la novela de Piñeiro, relacionándolas, a su vez, con las pieles totémicas asumidas por Felipe Guamán Poma de Ayala, desde su propio nombre. Rodríguez vincula a las dos obras precisamente en la capacidad de transformación y mediación que proporciona la piel, que podemos relacionar, como vimos al principio de este ensayo, con lo textil:

Por tanto, la adopción de estas pieles supone el surgimiento de un ser múltiple. Es precisamente a partir de la facultad de transformación andina - por la que se convierte en otro, sin dejar de ser él mismo y con los poderes creativos de esta relación con lo sagrado- que, a la manera de Sara Chura, Guamán Poma se dota del saber, el sentir y el poder para emprender su monumental obra. (240)

Elénfasis en la piel, por encima de la máscara, señala para Rodríguez el compromiso político de la novela que, más allá del carnaval occidental identificado por Bajtin, consigue "forjar específicamente el pacto simbólico con el mundo andino cuyas convenciones se marcan como la piel oscura, misteriosa y secreta en principio de la fiesta, de la ciudad, del país y de sus habitantes" (242).

La Paz, ciudad de recién llegados y de viajeros en tránsito (Piñeiro 15), concentra la pesquisa de este detective aleatorio y abre sus caminos a los distintos personajes. Es también un recorrido por formas literarias apropiadas del archivo occidental. Don Quijote en La Paz y Hamlet en el ayllu de Macha, tejen una red intertextual, de sustracción paródica, que en la apropiación literaria manifiesta su pertenencia a un acervo transnacional y reafirma su capacidad de acción en él. Ello se evidencia sobre todo en Juan Chusa Pankataya, inefable Bartleby paceño, que se traduce y afirma, eco de la infinita burocracia latinoamericana, en su reiterado "Mañana nomás". De la parálisis que el choque con la ciudad, las relaciones capitalistas y lenguaje huero le provocan al personaje, lo saca una waka surgida nada menos que del asfalto:

Revista Iberoamericana, Vol. LXXXI, Núm. 253, Octubre-Diciembre 2015, 1033-1050 
La waka, que era invocada para regresar, miró al postizo inquisidoramente y le dijo: -El mundo es el conjunto de nuestras palabras. Eres el espejo de ciertas repeticiones. Te has apropiado de un vocabulario vacío para terminar de vaciarte tú. Yo puedo ayudarte a regresar.

Juan Chusa no dijo nada pero inmediatamente supo que para volver al mundo, debía encontrar la forma de ser un comunario, a pesar de vivir en la ciudad. (106)

Como vemos, el choque entre racionalidades opuestas y la herida profunda de la conquista no se apagan en el relato. Las tensiones se manifiestan en la atonía del migrante recién llegado, en vampiros como el karisiri, que extrae la grasa de sus víctimas para procesarla en la industria farmacéutica internacional (una leyenda viva, que Viveiros de Castro relaciona con la extracción de la conquista y que Silvia Rivera Cusicanqui recoge en el norte de Potosí vinculada a las acciones de las ONG's), o en la propia incertidumbre que está en el título de la novela. Pero el dolor no se resuelve en el lamento, sino en la fiesta, que trae emparejada la memoria y la exaltación del propio cuerpo. La imagen de la lluvia de muertos convertidos en semilla, con que termina el desfile triunfal de Sara Chura, alude a esa capacidad de regeneración y fecundidad que, integrado en las técnicas y espacio simbólico del tejido andino, también estaba presente en El pez de oro. Lo andino en estas obras está en movimiento constante, como un tejido maravilloso, hecho de memoria e infinitas posibilidades:

El aqsu que la cubrirá cambiará de colores y diseños, vertiginosamente, a cada segundo, a cada instante, y será un textil perfecto, el tejido del movimiento, lo que protegerá su piel subterránea de los rayos del sol atardeciendo en la ciudad [...]

Entonces en su ropa, en su vestimenta, en el tejido que la diferencia del mundo salvaje, indomable y sediento de los cerros y los cielos, de los lagos, de los zorros, de las aves, de los sapos y las serpientes, y los pumas, de las lagunas tornasoles y las cuevas de adentro, donde ella camina perseguida por la luz, aparecerán infinitas tejedoras, arrodilladas como monjes budistas en la vasta y microscópica tierra morena: la piel de Sara y la temperatura de su sangre. Y cada una usará dos estacas de madera para agrupar los hilos que estarán tejiéndose, vistiendo a la mujer que será todas las mujeres el día en que Sara Chura despierte. (Piñeiro 80)

Revista Iberoamericana, Vol. LXXXI, Núm. 253, Octubre-Diciembre 2015, 1033-1050 
BiBLIOGRAFÍA

Adorno, Rolena. Guaman Poma. Writing and resistance in Colonial Peru. Austin: U of Texas P, 2000.

Arguedas, José María. "Notas elementales sobre el arte popular religioso y la cultura mesttiza de Huamanga". Formación de una cultura nacional indoamericana. México: Siglo XXI, 1989.

Arnold, Denise Y. "Cartografías de la memoria: hacia un paradigma más dinámico y viviente del espacio”. Cuadernos FHyCS-UNju 36 (2009): 203-244.

Castro, Eduardo Viveiros de. A inconstancia da alma selvagem. São Paulo: Cosacnaify, 2002.

Cereceda, Verónica. "Aproximaciones a una estética andina: de la belleza al Tinku". Tres reflexiones sobre el pensamiento andino. La Paz: Hisbol, 1987.

"Semiología de los textiles andinos: las talegas de Islunga". Chungara 42 (2010): 181-198.

Churata, Gamaliel. El pez de oro. La Paz: Canata, 1957.

Colectivo Simbiosis y Colectivo Situaciones. De chuequistas y overlockas: Una discusión en torno a los talleres textiles. Buenos Aires: Tinta Limón, 2011.

Cornejo Polar, Antonio. "El indigenismo y las literaturas heterogéneas. Su doble estatuto sociocultural". Sobre literatura y crítica latinoamericanas. Caracas: Universidad Central de Venezuela, 1982.

Corominas, Juan. Breve diccionario etimológico de la lengua castellana. Madrid: Gredos, 1998.

Desrosiers, Sophie. "Lógicas textiles y lógicas culturales en los Andes". Travaux de l'IFEA 97 (1997): 325-349.

Gisbert, Teresa, Silvia Arze, Silvia y Martha Cajías. Arte textil y mundo andino. La Paz: Plural, 2010.

Guamán Poma de Ayala, Felipe. Nueva corónica y buen gobierno. México: FCE, 2005. Nueva Corónica y Buen Gobierno. Edición digital de la Biblioteca Real de Dinamarca. <http://www.kb.dk/permalink/2006/poma/info/es/project/project. htm>.

López-Baralt, Mercedes. Para decir al Otro. Literatura y Antropología en nuestra América. Madrid/Frankfurt am Main: Iberoamericana/Vervuert, 2005.

Morales, Bruno (Sergio di Nucci). Bolivia construcciones. La Paz: Yerba Mala, 2008.

Monasterios, Elizabeth. "“Awqa': donde las cosas no pueden estar juntas. Notas para una post-metafísica aymara". Memorias de JALLA Tucumán 1995. Vol. I. Tucumán: Proyecto “Tucumán en los Andes”, 1997. 753-762.

"Uncertain Modernities: Amerindian Epistemologies and the Reorienting of Culture". A Companion to Latin American Literature and Culture. Sara CastroKlaren, ed. Malden: Blackwell Publishing, 2008. 553-569.

Revista Iberoamericana, Vol. LXXXI, Núm. 253, Octubre-Diciembre 2015, 1033-1050 
"La vanguardia plebeya del Titikaka". La Mariposa Mundial. Revista de literatura. 19/20. La Paz: Plural, 2012. 39-49.

Piñeiro, Juan Pablo. Cuando Sara Chura despierte. La Paz: Gente Común, 2009.

Rivera Cusicanqui, Silvia. Ch 'ixinakax utxiwa: una reflexión sobre prácticas y discursos descolonizadores. Buenos Aires: Tinta Limón, 2010.

Violencias (re)encubiertas en Bolivia. La Paz: La mirada salvaje, 2010.

Rivera Cusicaqui, Silvia y El Colectivo. Principio Potosí Reverso. Madrid: Museo Nacional Centro de Arte Reina Sofía, 2010.

Rodríguez Márquez, Rosario. De mestizajes, indigenismos, neoindigenismos yotros: la tercera orilla (sobre la literatura escrita en castellano en Bolivia). Tesis Doctoral. $\mathrm{PhD}$ in Hispanic Languages and Literatures. University of Pittsburgh, 2008.

Solanilla Demetre, Victoria. "El rol de las tejedoras precolombinas a través de las fuentes e imágenes”. Destiempos 18 (2009): 84-97.

Revista Iberoamericana, Vol. LXXXI, Núm. 253, Octubre-Diciembre 2015, 1033-1050 